\title{
RESEARCH
}

\section{Between Two Ills: Homonationalism, Gender Ideology and the Case of Denmark}

\author{
Malte Breiding Hansen \\ Lund University, DK \\ ma1681ha-s@student.lu.se
}

\begin{abstract}
This article draws on Mouffe's theory of agonistic democracy and critique of hegemonic consensuses to examine whether and how homonationalism can come to fuel antagonisms levelled against the gender+ movements. Using discourse analysis, the article analyses the case study of Denmark, where in 2018 the anti-gender campaign openly challenged the government's homonationalist discourse. The analysis confirms that the government's homonationalist discourse establishes modes of exclusion from the national imaginary, which the anti-gender actors contest by articulating an antagonism levelled against the gender+ movements' attributed queer ideology. The antagonising potential of homonationalist discursive practices is further substantiated by pointing to the ways in which the government's discourse reinforces a liberal idea of citizenship that gives priority to liberal rights over the democratic values of popular sovereignty and participation. Conversely, the anti-gender discourse gives priority to popular sovereignty at the expense of gender minority rights. Both the governments' and the anti-gender actors' discourses are thus found to fall short in terms of the prescripts of an agonistic public sphere. The article therefore argues for an abandonment of homonationalist discursive practices, when manifesting as a hegemonic consensus, which reinforces a liberal idea of citizenship to install a plural agonistic public sphere concerning sexual and gender minority politics.
\end{abstract}

Keywords: homonationalism; agonistic democracy; anti-gender campaigns; gender ideology; LGBT rights

\section{Introduction}

Since the early 2000s, campaigns and protests mobilising against the enemy image of 'gender ideology' have emerged across Europe. These campaigns showcase such strategic and discursive similarities that the emerging scholarship has come to designate them as belonging to a European movement, an anti-gender movement, which cannot be understood as a mere continuation of former conservative mobilisations against gender and sexuality (Kuhar \& Paternotte 2017a). Despite national specificities, these anti-gender campaigns all share a basic narrative: that of a majority suffering under the tyranny and imposition of a 'gender ideology' (Kuhar \& Paternotte 2017b, 253). It has thus been characterised by scholars as an 
illiberal populist right-wing discourse, which establishes antagonistic relations against the gender+ movements ${ }^{1}$ perceived as a powerful gay and radical feminist lobby (Mayer \& Sauer 2017, 23). This discursive strategy was originally launched by the Vatican, when 'gender' was introduced in official UN language in the 1990s (Case 2019; Corredor 2019, 615; Korolczuk 2017, 293). Since then, various religious and right-wing groups have taken up this discursive strategy in many European countries (and elsewhere, especially Latin America). As a 'symbolic glue', 'gender ideology' has thereby proven itself successful in coalescing a wide range of groups and movements (Grzebalska, Kováts, \& Pető 2018, 34), a coalitional success that has been ascribed to the rather vague denomination of 'gender ideology' (Mayer \& Sauer 2017, 23).

Also in Denmark, an anti-gender campaign unfolded during the second half of 2018. On 6 June 2018, the Danish centre-right coalition government ${ }^{2}$ launched an 'Action plan to promote security, well-being and equal opportunities for LGBTI people' (Handlingsplan til fremme af tryghed, trivsel og lige muligheder for LGBTI-personer) - henceforth, 'LGBTI action plan' - which consisted of around 40 different initiatives (Regeringen 2018). On 16 June 2018, three chairmen of Evangelical Christian organisations denounced a so-called 'queer ideology', ${ }^{3}$ which they believed had infiltrated the government's action plan and would result in immense societal consequences (Bækgaard et al. 2018). At the launch of the LGBTI action plan and during the subsequent Copenhagen Pride Week in August, the Prime Minister, Minister of Equality and Minister of Health held a number of speeches. Especially PM Lars Løkke Rasmussen's speech on 18 August 2018 on Copenhagen City Square marking the Copenhagen Pride parade procession further instigated an anti-gender offensive in national media (Rasmussen 2018). In this speech, PM Rasmussen declared that Denmark must object to the 'stock-conservative view of human nature of the past' and stated that people who have pro-LGBTI attitudes 'are Denmark' (Ibid.). In a series of opinion pieces, interviews, tv- and radio appearances, the Evangelical Christian organisations ${ }^{4}$ (henceforth, anti-gender actors) condemned PM Rasmussen's act of connecting pro-LGBTI attitudes to the nation and argued that they felt discounted as Danish citizens. In that sense, the anti-gender rhetoric became entangled with a discursive struggle over national identity.

${ }^{1}$ I apply the term 'gender+ movements' to designate the feminist and LGBT+ (lesbian, gay, bisexual, trans, etc.) movements.

2 The centre-right coalition government is the author of the LGBTI action plan, but the agreement to allocate the funds and the general initiatives was agreed upon by an equal number of parties from the left and right, including the current governing centre-left party. This reflects the general political culture in Denmark, which is characterized by a strong culture of compromise and consensus across the left-right divide. This is not least due to the fact that most governments throughout newer Danish history have been minority governments, as no single party has had a majority in parliament since 1909. Therefore, coalition governments are no rare sight in the Danish multi-party system (Bille 2006). As such, the action plan has been carried on in its original form by the new centre-left government, which was formed in 2019, and might thus be said to represent a hegemonic manifestation of LGBTI politics in Denmark.

${ }^{3}$ Depending on the national context, the anti-gender activists use various terms to label what they oppose: gender, gender studies, genderism and gender ideology, with the latter being the most prevalent. In Denmark, the anti-gender actors predominantly use 'queer ideology', which I have not found mentioned in other studies on anti-gender campaigns. However, they also use gender ideology (kønsideologi) interchangeably a few times. I will refer to that which the anti-gender actors oppose as 'queer ideology', whereas I adhere to the term 'gender ideology' when discussing the general literature on the anti-gender movement.

${ }^{4}$ The full list of organisations officially stated as part of the anti-gender offensive after PM Rasmussen's speech at Copenhagen Pride: the three independent Lutheran revival movements, Indre Mission (IM), Luthersk Mission (LM) and Evangelisk Luthersk Mission (ELM); the Evangelical Lutheran network for Christians in Denmark, Evangelisk Luthersk Netværk (ELN); the educational and theological institute Kristent Pædagogisk Institut (KPI); The private theological educational institutions Menighedsfakultetet i Aarhus and Dansk Bibel Institut (DBI). 
Taking the cue from the Danish anti-gender campaign, this article considers how homonationalism can play a part in fueling antagonisms against the gender+ movements, when the former manifests as an exclusionary consensus. Drawing on Chantal Mouffe's theory of agonistic democracy (Mouffe 1993; 2000; 2005; 2013; 2018), homonationalism (Puar 2017 [2007]) is approached as a discursive practice that can manifest as a hegemonic consensus, which includes sexual and gender minorities in the national imaginary while simultaneously labelling ethnic and religious minorities as morally backwards. Following Mouffe, such modes of homonationalist exclusions could risk turning from a simple assertion of difference into a friend/enemy antagonism, such as an anti-gender political position. Thus, this article seeks to further a critique of homonationalist politics from the perspective of agonistic democratic theory.

The article is structured as follows: In the first section, I present Mouffe's theory of agonistic democracy and how Puar's theory of homonationalism might be understood to hold the potential of manifesting as an exclusionary consensus. In the second section, I show how Mouffe's theory has been leveraged in the interpretation of the anti-gender movement in Europe. In the third section, I provide a short note on the discourse-theoretical approach to discourse analysis employed in the analysis of the Danish case. In the fourth and fifth sections, I present the Danish government's homonationalist discourse and the anti-gender actors' counter-discourse, respectively. In the sixth section, I qualify the findings by considering the opposing ideas of citizenship found in the two discourses and how they run against the prescripts of an agonistic public sphere. I argue that homonationalist discursive practices, when figuring as an exclusionary consensus that reinforces a liberal conception of citizenship, hold the risk of fueling antagonisms against the gender+ movements, and in that sense need to be abandoned.

\section{Agonism and Homonationalist Exclusions}

Chantal Mouffe's theory of agonistic democracy states that democracy is in peril when a healthy confrontation of political views is 'hindered by an apparent excess of consensus' (Mouffe 1993, 6). What she terms 'Europe's populist moment' is therefore the expression of a state of post-democracy, where a healthy confrontation of views between different societal projects has been foreclosed, and '[p]olitics therefore has become a mere issue of managing the established order' (Mouffe 2018, 17). Thus, 'excessive consensuses' lead to a de-politicisation and technocratisation of the political arena. Faced with such consensuses, people increasingly lack political positions with which to identify to channel frustrations and disagreements with the status quo through the political system. As a result, people begin to identify and mobilise around non-negotiable moral values or essentialist forms of identifications, such as, for example, religious, nationalist or ethnic, because they provide the people with a political position that contests the status quo (Mouffe 2005a, 124). According to Mouffe, the task of liberal democracies, and democratic theory proper, is therefore not one of instituting a fully inclusive consensus, a 'we', without exclusion. Rather, the goal is to find ways to articulate an us/them relation whereby "conflict does not take the form of an "antagonism" (struggle between enemies) but the form of an "agonism" (struggle between adversaries)' (Mouffe 2013, 7). An antagonism can therefore be understood as an act of articulation whereby the symbolic space is represented as consisting of two opposed blocs pitted against each other as enemies rather than as legitimate adversaries in a democratic struggle for hegemony.

This article considers homonationalism as a discursive practice that can manifest as such an 'excessive' consensus and thus potentially become implicated in antagonistic dynamics levelled against the gender+ movements. Homonationalism can be described as the idea that the nation is constructed as inherently open and welcoming to sexual and gender minorities 
in opposition to the (allegedly) homo- and transphobic attitudes of racial, cultural and religious others, most often Muslim (Puar 2017, 228; Schotten 2016, 354). Hence, the theory of homonationalism critiques the proposition by transnational feminists and queer theorists that the nation is inherently heteronormative and that it thereby renders queer folks outlaws of the national imaginary (Puar 2017, 225; 2013, 24). Instead, homonationalism points to a historical shift whereby, '[h]omosexuals once on the side of death (AIDS) are now on the side of life or are productive for nation-building' (Puar 2013, 35).

Puar highlights three imbricated manifestations of homonationalism demarcating nationally accepted citizens from non-citizens, that is, creates exclusionary us/them relations: sexual exceptionalism, queer as regulatory and ascendancy of whiteness. First, sexual exceptionalism is a 'praxis of sexual othering' that constructs the nation as exceptional and itself an exception from other, most often Muslim, populations, when it comes to its treatment of LGBTI people (Puar 2017, 4). Second, queer as a regulatory frame highlights how particular conceptions of the liberated queer subject are folded into the national imaginary against people perceived to abide to an irrational religiosity (Ibid., 23). Finally, the ascendancy of whiteness denotes how the hegemony of whiteness is consolidated through multiculturalist inclusion by distinguishing a tolerable ethnic (an exceptional patriot, for example) from an intolerable ethnic (a terrorist suspect)' (Ibid., 25).

Hence, in Puar's formulation of homonationalism, we find a theoretical elaboration of discursive practices that establish exclusionary us/them relations between the pro-LGBTI people and anti-LGBTI other. Following Mouffe, such an act of exclusion holds the risk of being transformed from a simple assertion of difference into an antagonistic friend/enemy relation (Mouffe 2005b, 9). However, I do not intend to suggest that what one might characterise as a homonationalist discursive practice always comes to establish a hegemonic consensus with antagonistic implications. It is therefore necessary to exemplify this consensus vis-à-vis antagonism dynamic. I do so by analysing the Danish case of an anti-gender campaign in 2018. The following section therefore briefly configures a prevalent interpretation of the emergence of the European anti-gender movement with Mouffe's theory.

\section{Agonism and Anti-Gender Campaigns}

Existing interpretations of the anti-gender movement already leverages Mouffe's theory more or less explicitly. One school, in particular, argues that anti-gender campaigns do not constitute mobilisations against gender+ equality per se (Rawłuszko 2019, 2). Rather, 'gender ideology' is invoked by the anti-gender actors as, 'a metaphor for the insecurity and unfairness produced by the current socioeconomic order' (Grzebalska, Kováts, \& Pető 2018, 34). As such, "'Gender ideology" has come to signify the failure of democratic representation, and opposition to this ideology has become a means of rejecting different facets of the current socioeconomic order' (Ibid.). In that sense, 'gender ideology' is a way of naming a host of frustrations with certain hegemonic consensuses and political 'common senses.'

A few scholars on the anti-gender movement indeed mobilise Mouffe's theory explicitly. Jenny Gunnarsson Payne argues that "gender" has come to play a central role in the construction of political frontiers in the currently polarised political situation that Chantal Mouffe [...] has called Europe's populist moment' (Payne 2019). Eszter Kováts (2017b; 2018a; 2018b) similarly argues that the anti-gender campaigns are the outcome of hegemonic consensuses among the 'so-called progressive actors' (Kováts 2017b, 2018b). As gender+ movements are being associated with such 'progressive consensuses', they are being held co-responsible for the experiences of precarity and exclusion that they generate (Kováts and Pető 2017, 127). 
To apply this Mouffean interpretation of anti-gender campaigns, one needs to recognise that national specificities matter for understanding what fuels or triggers such national anti-gender mobilisations. That is, anti-gender mobilisations in Europe from 2010 onwards were and are triggered by nationally specific policy debates (Kuhar \& Patternotte 2017b, 256). Although Kováts proposes 'human rights' and 'neoliberalism' as what one might call cross-national master-consensuses to have brought about anti-gender antagonisms on a larger scale (Kováts 2017b; 2018a; 2018b), the exact configuration and 'face' of a consensus most often bear unique traits, which must be derived from the national context under study. In this study, homonationalism is therefore considered as one of such triggering policy debates that came to fuel and intensify an anti-gender mobilisation in Denmark. However, this is, of course, not to deny that other factors also played a part in building negative sentiments towards the gender+ movements.

\section{Method}

To consider the potential antagonistic implications of homonationalist exclusions, I analyse the Danish anti-gender campaign in 2018, where the gender+ movements were accused of infiltrating the government's LGBTI action plan with their 'queer ideology.' I present the government's discourse and its contestation by the anti-gender actors. Choosing to analyse the Danish government's articulations is not meant to imply that any discursive elements in the government's discourse cannot be said to flourish among selected gender+ organisations and actors such as moralistic iterations of human rights-discourses or even homonationalist expressions. Those would need to be taken into account if one wishes to establish the full picture of why the anti-gender mobilisation emerged in the Danish context. However, the aim of this study is more modest and merely seeks to explore the antagonising implications of homonationalism. Thus, I delimit the analysis to a particularly strong state-sponsored articulation by the Danish government.

I adopt Stavrakakis and De Cleen's discourse-theoretical approach to analysing nationalist and populist discourses, understood as 'distinct ways of discursively constructing and claiming to represent "the people", as underdog and as nation respectively' (De Cleen \& Stavrakakis 2017, 301; emphasis added). The government's discourse is approached as a nationalist discourse, whereas the anti-gender actors' discourse is considered a populist discourse. A nationalist discourse articulates a social frontier between the 'citizen' and the 'non-citizens' of the nation, whereas a populist discourse articulates a social frontier between the 'member of the people' and the illegitimate elite, oligarchy, ancient regime. I find this approach particularly convincing, because it provides a way of delineating the us/them relation (citizen/non-citizen) in the government's discourse, which could turn into an antagonistic friend/enemy relation and how, in turn, such an antagonism might be found in the anti-gender actors' articulation of a social frontier between the people-as-underdog and the gender+ elite.

\section{Danish Homonationalism: Trailblazer of the World}

I will begin by presenting the government's discourse as articulated by the state officials of the Danish centre-right coalition government in speeches ${ }^{5}$ during the launch of the action plan (Hansen 2018a; MrXQ28dk 2018a; 2018b) during Copenhagen Pride in 2018 (Hansen 2018b; 2018c; Rasmussen 2018) as well as in the LGBTI action plan (Regeringen 2018).

\footnotetext{
${ }^{5}$ The selection criteria for the government's speeches was that they had to be held by state officials during the launch of the LGBTI action plan and address LGBTI issues. In addition, the speeches either (or both) had to be available to the public on Ministry websites or held at public events in order to analyse the official political consensus among state officials.
} 
First, the government defines the nation as exceptional due to its adoption of LGBTI freedoms and rights. The government thus leverages a discourse of sexual exceptionalism by presenting the Danish nation as a 'frontrunner' (foregangslands) and 'the first country in the world' when it comes to adopting formal liberal rights for LGBTI persons (Hansen 2018a; 2018c; MrXQ28dk 2018a; 2018b). The Minister of Equality, Eva Kjer Hansen, for example, states the following:

Every legislative improvement we have made in the rights of gay and transgender people has been controversial in their time. That was the case when Denmark became the first country to pass a registered partnership law. When Denmark became the first country to recognize two legal parents of the same gender [køn]. When Denmark became the first European country to allow legal gender change [juridisk kønsskifte]. And when Denmark, last year, became the first country in the world to change its legislation, so that being transgender is not diagnosed as a mental illness (Hansen 2018c). ${ }^{6}$

Denmark has thereby 'taken one impressive step after another and been the first to most' (Ibid.). By extension, Denmark is presented as a trailblazer, inspiration and an example to follow for other nations. PM Rasmussen, for example, declares that Denmark is, "[a] country that shows the way. In many areas. That is why other countries often look to us for inspiration' (Rasmussen 2018).

Secondly, the Danish nation is attributed with what is termed a 'liberal-mindedness' (frisind). This liberal-mindedness refers to a particular view of human nature where: 'we are all human beings first and everything else thereafter' (MrXQ28dk 2018a; Rasmussen 2018). In other words, one is an individual prior to any religious and cultural norms and traditions. PM Rasmussen declares that Denmark's formal rights for LGBTI subjects need to be accompanied by a change of conscience that will turn the 'exceptional' LGBTI freedoms and rights into a liberal-mindedness among the Danish people (MrXQ28dk 2018a; Rasmussen 2018). In other words, the government seeks to institute a 'liberal-minded' pro-LGBTI consensus, a 'common sense', among all parts of the people.

Entry into national belonging, that is, identifying as citizen of the nation, is therefore contingent upon, not only the acceptance of rights for LGBTI subjects but the internalisation of this particular 'liberal-minded' view of human nature. This is most evident in PM Rasmussen's speech at Copenhagen Pride, where he ascribes this liberal-mindedness to the people who stood on the sidewalk watching the pride procession:

And not least thank you - yes, a special thank you - to all of you who stood along the [pride parade] route. With wide smiles on the face. Joy in the eyes. And liberalmindedness in heart. You are Denmark (Rasmussen 2018; emphasis added).

The subject position of the citizen is thus articulated in the image of people who have proLGBTI attitudes and see LGBTI people as individuals prior to any other classification. By extension, LGBTI people's well-being is presented as contingent upon their ability to be open about their sexual orientation and gender identity at work, in their family and in the public sphere (see e.g. Regeringen 2018, 17). The liberal-mindedness of the Danish population is, in that sense, evaluated in terms of LGBTI people's willingness to 'come out of the closet' and express themselves. As such, the government articulates equivalential links between the freedom and equality of LGBTI persons, and the 'coming out' as a prosperous and developed

${ }^{6}$ All quotes from the government and the anti-gender actors are translated from Danish to English and are my translations. 
nation: 'Freedom and equality are crucial to the individual human's opportunities and to the prosperity, development and economic growth of a country' (Ibid., 33). 'Queer as regulatory' thereby figures in the government's discourse by sanctioning the liberated, open and fully realised LGBTI person, which they can only be if the 'liberal-minded' pro-LGBTI consensus spreads to all parts of the population.

In line with Mouffe's theoretical propositions, this 'liberal-minded' consensus relies on a concomitant exclusion of the non-members, the constitutive other, of the nation. Apart from other nations, regions and continents (Hansen 2018b; 2018c; Regeringen 2018, 33), nonmembers of the nation are identified as those who do not subscribe to the 'liberal-minded' view of human nature that defines the nation and mode of citizenship. PM Rasmussen states in his speech at Copenhagen Pride:

For me, Copenhagen Pride is a manifestation. For freedom, liberal-mindedness and community [fcellesskab]. A message to every corner of Denmark. Every part of Europe. Every area of the world - that [...] we here in this country object - as in completely - to forces that want the stock-conservative [forstokket] view of human nature of the past. That we in our society - our country - stand together for the right to be who one is (Rasmussen 2018).

A dichotomy of national belonging/non-belonging as citizen is thereby established between people subscribing to the 'liberal-minded' consensus and people having 'the stock-conservative view of human nature of the past.' This 'stock-conservative view of human nature' is racially, culturally and religiously inflected:

For the government, equal opportunities regardless of gender, sexual orientation or gender identity are a premise that everyone must accept - a premise that cannot be bent on culture, tradition or religion neither out in the world or at home. Freedom, equal status and equal opportunities are our common values. And there should be no doubt that we are human beings first - everything else thereafter (Regeringen 2018, 5).

The communitarian signifiers, 'culture', 'tradition' and 'religion', are racially inflected by attributing such communitarian 'stock-conservatism' to ethnic minority constituents by consistently pointing out 'ethnic minority LGBTI persons' as representing the most vulnerable sub-group (Hansen 2018a; 2018b; MrXQ28dk 2018a; Regeringen 2018, 5) - especially those who, 'come from environments and families characterized by rumors and strong traditional family patterns and norms' (Regeringen 2018, 13-14). Although the most prevalent term applied is 'ethnic minority', the Minister of Equality specifies that, 'especially Muslim LGBT-persons are being exposed to violence and social control' (Hansen 2018b; emphasis added). Thus, the ascendancy of whiteness works through the construction of proper ethnic LGBTI persons who ascend into the white national imaginary by disassociating themselves from the attributed stock-conservative human ontology among ethnic minority communities. In that sense, the government's annexation of a 'coming-out'-narrative 'is contingent upon the segregation and disqualification of racial and sexual others from the national imaginary' (Puar 2017, 2). A similar gender exceptionalism has been pointed out to be hegemonic in Danish public debate, which projects male sexual violence onto ethnic minority communities (Leine, Mikkelsen, \& Sen 2019). As will become evident, the anti-gender actors dislocate the government's racialised denomination of the nation's other by explicitly identifying their own position as a defense of 'stock-conservative' communitarian views on sexuality and gender. 


\section{V.I. The False Consciousness of Queer Ideology}

I will now turn to the anti-gender actor's discourse as articulated through various media representations. ${ }^{7}$ Let me begin with the constitutive other in the anti-gender discourse, the 'queer ideology.'

One might distinguish between what the anti-gender actors mean by (i) queer and (ii) ideology. Starting with the former, the anti-gender actors present the 'queer ideology' as a view of human nature, constituting, 'a striking movement, which has shifted our view on what kind of humans we are, how we are wired as gendered beings' (Asmussen in Aftenshowet 2018). Thereby, they draw on the same discursive resources as the government, by approaching the question of LGBTI rights and recognition as a matter of determining what constitutes human nature. Their definition of queer and queer ideology as provided in the anti-gender actors' opinion piece in Kristeligt Dagblad is worth stating in full:

[Queer ideology is] a sense of reality that completely drops traditional gender identity in order to leave gender identity fluid and self-chosen and with many more options than just man and woman. Gender must not be subject to biological restrictions and there must be no limits to sexual practices or behavior. One must choose what is normal, without facing discrimination or criticism. Therefore, a free and unlimited identity is celebrated, where you consciously discard all the markers of identity that categorise the majority of humanity (Bækgaard et al. 2018).

The queer ideology thereby eradicates 'traditional gender identities', that is, 'man' and 'woman', and instates an ultra-libertarian notion of gender enforced on all individuals in its place. Queer ideology is therefore said to propagate a conception of gender identity, which is 'fluid', 'selfelected' and 'self-constructed' (News \& Co 2018; Nue 2018; Schaumann 2018). By defining the queer ideology's conception of gender identity as a radically free personal choice, the antigender actors thus link the queer ideology to a growing 'extreme individualism' in Danish society; that is, where every individual is expected to define and realise themselves and 'find one's own way' beyond any biological or normative restrictions (Deadline 2018; Schaumann 2018).

It is important to note, that this characterisation of a queer view of human nature, which they claim stems from queer theory, builds on a certain misrepresentation of what it means to say that gender is performative. In Denmark, there's only one word for gender: køn. When the anti-gender actors apply 'traditional gender identities', they refer to biologically determined assigned sex, whereas their use of the term queer is used to denote a kind of unrestricted self-determination - a radically free choice - when it comes to gender identity. Thus, they disregard the social relations of power through which queer theory argues that gender comes into being. Further, adhering to a queer theoretical, or performative, understanding of gender does not imply the eradication of gender identities such as 'man' and 'woman.' As Butler states in her seminal work, Gender Trouble (1999), that gender is performative is not a matter of demarcating true from false genders but aims to celebrate the radical diversity inherent in the real gender (Butler 1999, 180).

\footnotetext{
${ }^{7}$ Various representatives of the anti-gender organisations appear in TV and radio programmes and in newspaper articles and interviews. The Chairman of IM, Hans Ole Bækgaard, represents the alliance in a segment on the journalistic talk show News \& Co (2018) on the channel TV2 News, an interview segment on the morning radio programme P1 Morgen (2018) and a TV reportage in the journalistic news programme 21 Søndag (2018) on the TV channel DR1. The head of communications of IM, Asbjørn Asmussen, appears in a debate segment in the journalistic talk show Aftenshowet (2018) on DR1. The Chairman of ELN, Jens Lomborg, is interviewed by Schaumann (2018) for the daily newspaper JydskeVestkysten and appears in a debate segment in the journalistic TV news program, Deadline (2018) on the TV channel DR2, together with a spokesperson for IM, Frederik Berggren Smidt. In addition, various Chairmen from the organizations provide statements in the newspaper articles by Lingren (2018) and Nue (2018) for the online newspaper DR Nyheder.
} 
This 'queer' view of human nature is by the anti-gender actors presented as having radical consequences, not only for the individual but for society in general. Changes in perceptions of gender are thereby linked to a general de-generation and transformation of society. As Sørensen argues:

We do not live for ourselves alone but for a greater community. It is not good for the human or society not to have a community. We need each other. If we give up on the norms, on which society is build, we will break up the communities, upon which society depends (Sørensen 2018).

In that sense, the subject owes its gender identity to the community as opposed to it being a property of the individual. In other words, 'traditional gender identities' are a communitarian public good, which the queer ideology, with its individualist foundation, seeks to disintegrate. Thus, the queer ideology is characterised as 'norm disintegrating' (normoplosende) or socially disintegrating (samfundsoplosende) (Bækgaard 2018; Bækgaard et al. 2018; Lingren 2018; News \& Co 2018). Human nature (understood as determined by biologically determined sex) is therefore presented as a structural category, which determines the stability and development of society.

What is then meant by queer ideology? First, the anti-gender actors present the above delineated queer view of human nature as a false consciousness, ${ }^{8}$ which as a Trojan horse ${ }^{9}$ covers up its real intentions and effects. As is argued in their opinion piece in Kristeligt Dagblad, ' $\mathrm{w}] \mathrm{e}$ foresee that the gender political project of the queer ideology will turn into what one believes to be combating, namely oppression, intolerance and abuse of power' (Bækgaard et al. 2018). The anti-gender actors thereby distinguish between what the Danish majority, the people, really wants and needs and what the queer ideology propagates. Their stated aim is to make visible the view of human nature and of society which lie behind the queer ideology, that is, "[b]ring into focus the consequences of the queer ideology so more people come to see for themselves what is at stake' (Bækgaard et al. 2018; emphasis added). The queer ideology is then a gender political project which is sold to politicians and the public under false pretenses (Deadline 2018; Schaumann 2018). As Jens Lomborg, chairman of ELN, states: '[w] e need to understand what kind of ideology lies behind when scratching a bit in the rainbow colors. [...] What is the goal at the end of the rainbow to put it that way?' (Deadline 2018).

On the basis of this construction of the queer ideology as an ideological view of human nature, anti-gender actors argue (and contest) that it has come to determine national belonging. Their main spokesperson, Bækgaard states that,

When the Prime Minister in connection with Copenhagen Pride talks about that in this country one objects to forces that want the stock-conservative view of human nature of the past, then I must assume that the Prime Minister refers to a person such as me. That I have a stock-conservative view of human nature when I want to maintain that there is something called man and woman. [...] It is problematic that I must experience not being able to count myself as a real Dane and someone who does not want our society, because I do not agree with what the Prime Minister was talking about. (Bækgaard in Lingren 2018; see also Bækgaard's statements in News \& Co. 2018; P1 Morgen 2018; 21 Søndag 2018).

\footnotetext{
8 I propose to understand the anti-gender actors' idea of ideology as 'false consciousness', that is, as a distortion of truth. In that sense, the anti-gender actors' discourse resembles a kind of ideology critique stemming from Marxism and the Frankfurt School (Jørgensen \& Phillips 2002, 179).

9 'Gender' as an ideological Trojan horse is a characterisation that stems from the Vatican (Payne 2019). Thus, the gender ideology is said to propagate an inherent untruth by trying to 'sneak in' LGBTI equality under the banners of equality between men and women (Rawłuszko 2019, 12).
} 
That is, making the queer ideology a matter of national belonging is presented as an enforced 'politically correct' consensus, which hinders democratic debate by silencing, stigmatising and discounting as illegimate anyone, who might question the existence of gender identities beyond those of 'man' and 'woman' (News \& Co 2018).

Importantly, the gender+ movements are targeted as the ones pulling the strings and thus having effected the kind of nationalist exclusion in the PM's speech. Lomborg, for example, states that the gender+ movements 'have to be mindful of the position of power you have right now, which is significantly greater than the one I have. That you do not exploit it intolerantly and totalitarian' (Deadline 2018). A 'norm-setting minority' (i.e. the gender+ movements) is therefore said to, not only take the people hostage under a false consciousness, including the politicians, but also to stigmatise critical voices (Aftenshowet 2018; Bækgaard 2018; Bækgaard et al. 2018; News \& Co 2018; Nue 2018). We thus see how the people are constructed as an underdog suffering under an illegitimate gender+ elite, which then comes to define membership of the people as being in a state of oppression and stigmatisation.

In short, the anti-gender actors articulate an antagonism by positing the gender+ movements attributed 'queer ideology', and the significance the latter is said to have gained for national belonging, as an enemy to the people. The queer ideology is attributed with the individualistic and exclusionary characteristics of the government's discourse but is nevertheless viewed as stemming from the success of the 'powerful' gender+ movements in infiltrating lawmaking and instating a distorting consensus. In the case of the Danish anti-gender campaign, we thus see a homonationalist consensus articulating us/them distinctions of national belonging which, in turn, is contested by the anti-gender actors by articulating an antagonistic people versus the gender elite relation. In other words, homonationalist exclusions play an important part in fueling an antagonistic dynamic levelled against the gender+ movement.

\section{V.II. The Right, the Good and the Antagonising Implications of Homonationalism}

Establishing that homonationalism can play a significant part in fueling antagonistic dynamics needs to be further elaborated, if we want to fully understand the theoretical basis from which to understand the antagonising implications of homonationalist exclusions from national belonging. To do so, I return to Chantal Mouffe's theory of agonistic democracy by pointing to the ways in which the government's homonationalist discourse runs against the propositions of an agonistic public sphere and the idea of citizenship that it presupposes. To circumvent blindly accommodating the anti-gender actor's alternative vision of society and citizenship, I will put their discourse to the same test.

Mouffe argues that: ' $[\mathrm{t}$ ]he recovery of a strong participatory idea of citizenship should not be made at the cost of sacrificing individual liberty' (Mouffe 1993, 62) - in that way, the liberal right and the communitarian good should remain in a productive tension, rather than one gaining predominance over the other (Mouffe 1991, 73). Mouffe therefore conceives of agonistic citizenship as a political identity, that is, a form of identification with the ethicopolitical values of liberty and equality (Mouffe 1991, 75; 1993, 65). As this allows for one to identify with different interpretations of these values (e.g. social democratic, neoliberal, radical democratic), 'the political community is held together not by a substantive idea of the common good but by a common bond, a public concern' (Mouffe 1993, 67).

As highlighted in the previous analysis, the point of contestation between the government's homonationalist discourse and the anti-gender actors' discourse comes down to a discursive struggle over whether to establish the liberal right of LGBTI persons over the communitarian good of 'traditional gender identities' or vice versa. In that sense, the homonationalist and anti-gender discourse show striking characteristics of what Mouffe calls the liberal and the communitarian tradition of citizenship, respectively. The liberal tradition (here she focuses on Kantian liberals such as Rawls) purports that, "individual rights cannot be sacrificed for 
the sake of the general welfare, [...] and that the principles of justice impose restrictions on what are the permissible conceptions of the good that individuals are allowed to pursue' (Ibid.). In that sense, citizenship is seen as 'the capacity for each person to form, revise and rationally pursue his/her definition of the good' (Ibid., 71). This resembles the government's homonationalist discourse, where the 'stock-conservative' views of human nature represent an impermissible conception of the common good in light of the rights of the LGBTI individual informing the pro-LGBTI identity of the nation. Conversely, communitarianism conceives of citizenship as common action for a common good, by emphasising, 'the notion of a public good, prior to and independent of individual desires and interests' (Ibid.). This resembles the anti-gender discourse, which forwards binary gender identity ('traditional gender identity') as the normative good for the community, independent of any one person's relation to their assigned gender.

Following Mouffe, the liberal conception of citizenship found in the government's homonationalist discourse runs against the prescripts of agonistic citizenship, because it discourages dimensions of public-mindedness and political participation. It does so, through the liberal individualistic inscription of human rights, whereby 'democracy is reduced to the defense of human rights at the expense of [...] popular sovereignty' (Mouffe 2005a, 128-129). The homonationalist co-constitution with a liberal idea of citizenship then creates the conditions for antagonism to emerge because it gives priority to the liberal values of pluralism and rights over the people's ability to continuously negotiate how these rights are to be interpreted and exercised.

One might even claim that such hegemonic notions of rights over popular sovereignty are further strengthened as a function of such rights gaining significance for national belonging. Following Mouffe, this moment of exclusion and its antagonistic potential cannot be comprehended within a liberal conception of citizenship, which views the people as consisting of individualised and atomised rights-bearers: '[o]ne of the main problems with liberalism - and one that can endanger democracy - is precisely its incapacity to conceptualize such a frontier' (Mouffe 2000, 43). In an interview, PM Rasmussen indeed portrays the antigender actors' arguments as, 'a strange insistence on having such opinions, that must be expressed in order to throw suspicion on people who are different' (21 Søndag 2018). He thereby expresses an inability to comprehend that the attribution of rights to sexual and gender minorities could have as an unintentional effect the exclusion of the anti-gender actors. According to Mouffe, "[t]o deny the existence of such a moment of closure [...] is to naturalize what should be perceived as a contingent and temporary hegemonic articulation of "the people" through a particular regime of inclusion-exclusion' (Ibid., 49). In that sense, homonationalism holds the risk of creating the conditions for antagonism to emerge due to a liberal denial of exclusion.

On the other hand, the communitarian view of citizenship proposed by the anti-gender actors is also problematic in installing an agonistic public sphere, because it purports the idea that society should, 'be organized around a single substantive idea of the common good' (Mouffe 1993, 62). Individual liberties are thus impinged upon, when citizens in that sense 'owes' their assigned gender to the community. Curiously, in their attempt to recover a participatory ideal - that is, call out the silencing implications of the queer ideology - the anti-gender actors come to devalue individual liberty. In other words, by installing the priority of the good over the right, the hegemony of individual liberty is merely replaced by the hegemony of the majority. In that sense, the power of the majority is not kept in check by gender minorities' right to freely identify with and live out a gender identity different from the one assigned at birth. As Kováts argues, "[a]nti-gender movements in this sense [...] acknowledge the political but negate pluralism. Therefore they pose a challenge to liberal democracy and to the actors committed to it' (Kováts 2017b, 178). 
Both the government's and the anti-gender actors' discourses are therefore incompatible with an agonistic order, because they articulate the precedence of one of the ethico-political values of liberal democracy over the other. That is, both discourses eliminate the constitutive tension necessary for a plural democracy. This calls for a general re-politicisation of citizenship belonging when it comes to LGBTI attitudes that discards the antagonising exclusions of homonationalist politics. As Kováts argues in the context of the European anti-gender movement, mirroring Mouffe, the anti-gender antagonisms should be sublimated, that is, 'tamed', by 'creating agonistic spaces for re-politicizing conflicts in a manner compatible with pluralist democracies' (Kováts 2018b, 536). This re-politicisation should not lead to the full realisation of the democratic logic of popular sovereignty but be kept in check by the liberal logic of rights and pluralism.

Realising that homonationalist discursive practices, when taking on the exclusionary form of a consensus that reinforces a liberal conception of citizenship, can fuel detrimental antagonistic dynamics against the gender+ movements does not mean that pro-LGBTI actors cannot still struggle to further liberal rights, democratic representation and cultural recognition for sexual and gender minorities. Such a struggle should merely allow for a mutual recognition of the struggle for hegemony that pro-LGBTI and anti-LGBTI actors both participate in; a struggle between adversaries rather than a struggle between enemies.

\section{Conclusion}

This article drew on Chantal Mouffe's theory of agonistic democracy to explore how homonationalism can come to fuel and become implicated in antagonistic dynamics levelled against the gender+ movements. In analysing the case of the anti-gender campaign in Denmark in 2018, I found that the government's homonationalist statements played a significant role in this deadlock by appropriating sexual and gender minority rights in the form of an exclusionary homonationalist discourse. I found that the central point of contention was between the nationalisation of a liberal individualism (government) and a gendered communitarianism (anti-gender actors). Drawing on Mouffe's critique of a liberal conception of citizenship, I argued that homonationalist exclusions further run against the prescripts of an agonistic public sphere when reinforcing a liberal conception of citizenship. However, this should not lead one to accommodate the communitarian idea of citizenship sponsored by the anti-gender actors. Rather, both conceptions of citizenship fall short of the prescripts of an agonistic public sphere in that the former gives priority to the values of liberty and rights, whereas the latter gives priority to the democratic value of popular sovereignty and participation at the expense of gender minority rights. To circumvent the antagonistic implications of homonationalist exclusions, I therefore argued, that homonationalist discursive practices need to be abandoned to sustain a productive tension between the liberal democratic values of liberty and equality.

Consequently, further research is warranted on how consensuses, and more specifically homonationalist modes of belonging, manifest and antagonise in other contexts. I believe that it is especially pertinent to take this form of theoretical and empirical analysis to the level of the EU. Anti-gender actors in East European countries especially singles out the EU and 'Brussels' as imposers of a gender ideology through technocratic instruments such as Europeanisation and gender mainstreaming (Rawłuszko 2019). One might then explore further the role 'homoeuropeanisation' (see, e.g. Ammaturo 2015; Colpani and Habed 2014; Slootmaeckers 2019) plays in fueling anti-gender antagonisms by drawing an exclusionary map of Europe between 'true' pro-LGBTI and 'not quite' anti-LGBTI Europeans. It is indeed pertinent to encourage a political re-orientation towards adversarial respect at a European scale if we want to circumvent a continuous race to the bottom - even when one's supposed 'enemies' currently show no intend to return the favour. 


\section{Acknowledgements}

I would like to thank Anthoula Malkopoulou for comments on an earlier version of this text as well as the insightful comments by the anonymous reviewers.

\section{Competing Interests}

The author has no competing interests to declare.

\section{References}

21 Søndag. September 16, 2018. 'Kønsdebatten Er Blevet Ensidig.' DR1. http://hdl.handle. net/109.3.1/df9ba3f8-3f6f-4668-9f25-bb275d7fc567 (May 19, 2020).

Aftenshowet. August 29, 2018. '[Title Unstated].' DR1. http://hdl.handle.net/109.3.1/5346 cd75-c10f-42f2-acec-da5fd6c3096f (May 19, 2020).

Ammaturo, Francesca Romana. 2015. 'The 'Pink Agenda': Questioning and Challenging European Homonationalist Sexual Citizenship.' Sociology 49(6): 1151-1166. DOI: https://doi. org/10.1177/0038038514559324

Bille, Lars. 2006. 'The Political System.' Ministry of Foreign Affairs of Denmark. http://www. netpublikationer.dk/um/6600/pdf/1_The_Political_System.pdf. (April 12, 2021).

Butler, Judith. 1999. Gender Trouble: Feminism and the Subversion of Identity. 2nd ed. New York: Routledge.

Bækgaard, Hans-Ole. 2018. 'Intet Må Være Normalt.' Indre Mission. http://indremission. $\mathrm{dk} / \mathrm{en} /$ budskab/blog/blogvisning/artikel/intet-maa-vaere-normalt/\#.XXzRB5MzaqA (September 14, 2019).

Bækgaard, Hans-Ole, Jens Lomborg, Henrik P. Jensen, and Per Ladekjær. 2018. 'Anerkend, at Køn Og Samliv Har Rammer-Lad Ikke Afsporet Kønsideologi Sætte Dagsorden.' Kristeligt Dagblad. https://www.kristeligt-dagblad.dk/debatindlaeg/anerkend-koen-ogsamliv-har-rammer-lad-ikke-afsporet-koensideologi-saette-dagsorden (September 14, 2019).

Case, Mary Anne. 2019. 'Trans Formations in the Vatican's War on 'Gender Ideology." Signs: Journal of Women in Culture and Society 44(3): 639-664. DOI: https://doi. org/10.1086/701498

Colpani, Gianmaria, and Adriano José Habed. 2014. "In Europe It's Different': Homonationalism and Peripheral Desires for Europe.' In LGBT Activism and the Making of Europe: A Rainbow Europe?, edited by Phillip M. Ayoub and David Paternotte, 73-93. New York: Palgrave Macmillan, DOI: https://doi.org/10.1057/9781137391766

Corredor, Elizabeth S. 2019. 'Unpacking 'Gender Ideology' and the Global Right's Antigender Countermovement.' Signs 44(3): 613-638. DOI: https://doi.org/10.1086/701171

Deadline.September 1, 2018. "[TitleUnstated]." DR2.http://hdl.handle.net/109.3.1/9d1ae954a803-4a27-b7ce-ac8b6f5ab619 (January 10, 2020).

De Cleen, Benjamin, and Yannis Stavrakakis. 2017. 'Distinctions and Articulations: A Discourse Theoretical Framework for the Study of Populism and Nationalism.' Javnost 24(4): 301-319. DOI: https://doi.org/10.1080/13183222.2017.1330083

Grzebalska, Weronika, Eszter Kováts, and Andrea Pető. 2018. 'Gender as Symbolic Glue: How 'Gender' Became an Umbrella Term for the Rejection of the (Neo)Liberal Order.' LuXemburg: Gesellschaftsanalyse Und Linke Praxis, 32-38.

Hansen, Eva Kjer. 2018a. 'Ligestillingsministerens Tale Til Lancering Af Regeringens Handlingsplan for Tryghed, Trivsel Og Lige Muligheder for LGBTI-Personer, Den 6. Juni 2018. Udenrigsministeriet. 2018. https://um.dk/da/om-os/ministrene/tidligere-ministres-talerog-artikler/eva-kjers-taler-og-artikler/tale-ved-lancering-af-lgbti-handlingsplan/ (April $15,2020)$. 
--_. 2018b. 'Ministerens Tale Til Reception for LGBTI- Miljøet i Forbindelse Med Copenhagen Pride Week, Den 14. August 2018.' Udenrigsministeriet. 2018. https://um.dk/da/ om-os/ministrene/tidligere-ministres-taler-og-artikler/eva-kjers-taler-og-artikler/tale-tilpridereception/ (April 15, 2020).

-_-. 2018c. 'Ministerens Tale Til Åbningen Af Copenhagen Prides Menneskerettighedsprogram, Den 14. August 2018.' Udenrigsministeriet. 2018. https://um.dk/da/om-os/ministrene/tidligere-ministres-taler-og-artikler/eva-kjers-taler-og-artikler/tale-prides-menneskerettighedsprogram/ (April 15, 2020).

Jørgensen, Marianne, and Louise Phillips. 2002. Discourse Analysis as Theory and Method. London: SAGE Publications, DOI: https://doi.org/10.4135/9781849208871

Korolczuk, Elżbieta. 2017. 'The Vatican and the Birth of Anti-Gender Studies.' Religion and Gender 6(2): 293-96. DOI: https://doi.org/10.18352/rg.10181

Kováts, Eszter. 2017b. 'The Emergence of Powerful Anti-Gender Movements in Europe and the Crisis of Liberal Democracy.' In Gender and Far Right Politics in Europe, edited by Michaela Köttig, Renate Bitzan, and Andrea Pető, 175-89. London: Palgrave Macmillan. DOI: https://doi.org/10.1007/978-3-319-43533-6

--- . 2018a. 'Conservative Counter-Movements? Overcoming Culturalising Interpretations of Right-Wing Mobilizations Against 'Gender Ideology." FEMINA POLITICA-Zeitschrift Für Feministische Politikwissenschaft 27(1): 75-88. DOI: https://doi.org/10.3224/feminapolitica.v27i1.07

--_. 2018b. 'Questioning Consensuses: Right-Wing Populism, Anti-Populism, and the Threat of 'Gender Ideology." Sociological Research Online 23(2): 528-538. DI: https://doi. org/10.1177/1360780418764735

Kováts, Eszter, and Andrea Pető. 2017. 'Anti-Gender Discourse in Hungary: A Discourse without a Movement?' In Anti-Gender Campaigns in Europe: Mobilizing Against Equality, edited by Roman Kuhar and David Paternotte, 117-32. London: Rowman \& Littlefield International, Ltd.

Kuhar, Roman, and David Paternotte. 2017a. "'Gender Ideology' in Movement: Introduction." In Anti-Gender Campaigns in Europe: Mobilizing against Equality, eds. Roman Kuhar and David Paternotte. London: Rowman \& Littlefield International, Ltd., 1-22.

---. 2017b. 'The Anti-Gender Movement in Comparative Perspective.' In Anti-Gender Campaigns in Europe: Mobilizing against Equality, edited by Roman Kuhar and David Paternotte, 253-276. London: Rowman \& Littlefield International, Ltd.

Leine, Marie, Henrik Hvenegaard Mikkelsen, and Atreyee Sen. (November 2019). "Danish Women Put up with Less': Gender Equality and the Politics of Denial in Denmark.' European Journal of Women's Studies. DOI: https://doi.org/10.1177/1350506819887402

Lingren, Daniel. 2018. 'Kirkelige Ledere i Fælles Front Mod Forskellige Kønsidentiteter: "Mennesket Er Skabt Som Mand Og Kvinde.' Berlingske. https://www.berlingske.dk/kultur/ kirkelige-ledere-i-faelles-front-mod-forskellige-koensidentiteter-mennesket-er-skabt (September 14, 2019).

Mayer, Stefanie, and Birgit Sauer. 2017. "Gender Ideology' in Austria: Coalitions around an Empty Signifier.' In Anti-Gender Campaigns in Europe: Mobilizing against Equality, edited by Roman Kuhar and David Paternotte, 23-40. London: Rowman \& Littlefield International, Ltd.

Mouffe, Chantal. 1991. 'Democratic Citizenship and the Political Community.' In Community at Loose Ends, edited by Miami Theory Collective, 70-82. Minneapolis and Oxford: University of Minnesota Press.

---. 1993. The Return of the Political. London: Verso.

--_. 2000. The Democratic Paradox. London: Verso. 
---. 2005a. 'For an Agonistic Public Sphere.' In Radical Democracy: Politics between Abundance and Lack, edited by Lars Tønder and Lasse Thomassen, 123-132. Manchester and New York: Manchester University Press.

---. 2005b. On the Political: Thinking in Action. London and New York: Routledge.

---. 2013. Agonistics: Thinking the World Politically. London: Verso.

---. 2018. For a Left Populism. London: Verso.

MrXQ28dk. 2018a. 'Lars Løkke Rasmussen LGBT.' YouTube. Denmark: MrXQ28dk. https:// www.youtube.com/watch?v=tkcZ3GWIcek (February 4, 2020).

-_-. 2018b. 'Sundhedsminister Ellen Trane Nørby.' YouTube. Copenhagen: YouTube. https:// www.youtube.com/watch?v=HVj-VOQX89M (February 4, 2020).

News \& Co. August 29, 2018. 'Kønsdebat: Kristne Organisationer Danner Fælles Front.' TV2 News, http://hdl.handle.net/109.3.1/48d67bd6-d933-4ff4-ba57-1f1e531cd6cb (May 19, 2020).

Nue, Josephine. 2018. 'Indre Mission: Queer-Ideologien Skal Ikke Være Definerende for Samfundet.' DR Nyheder. https://www.dr.dk/nyheder/indland/indre-mission-queer-ideologien-skal-ikke-vaere-definerende-samfundet (September 14, 2019).

P1 Morgen. August 30, 2018. '[Title Unstated].' P1. http://hdl.handle.net/109.3.1/80718f26fb77-427a-9df4- cdae185935bc (May 19, 2020).

Payne, Jenny Gunnarsson. 2019. 'Challenging 'Gender Ideology': (Anti-)Gender Politics in Europe's Populist Moment.' The New Pretender. http://new-pretender.com/2019/02/10/ challenging-gender-ideology-anti-gender-politics-in-europes-populist-moment-jennygunnarsson-payne/.

Puar, Jasbir K. 2013. "Homonationalism As Assemblage: Viral Travels, Affective Sexualities." Jindal Global Law Review 4(2): 23-43.

--_. 2017. Terrorist Assemblages: Homonationalism in Queer Times. 2nd ed. Durham: Duke University Press. DOI: https://doi.org/10.1215/9780822371755

Rasmussen, Lars Løkke. 2018. 'Statsminister Lars Løkke Rasmussens Tale Ved Copenhagen Pride Den 18. August 2018.' Statsministeriet. Copenhagen: Statsministeriet. http://www. stm.dk/_p_14716.html (March 12, 2020).

Rawłuszko, Marta. 2019. 'And If the Opponents of Gender Ideology Are Right? Gender Politics, Europeanization, and the Democratic Deficit.' Politics \& Gender. 1-23. DOI: https://doi. org/10.1017/S1743923X19000576

Regeringen. 2018. 'Handlingsplan Til Fremme Af Tryghed, Trivsel Og Lige Muligheder for LGBTI-Personer.' Regeringen. Copenhagen. https://www.regeringen.dk/media/5348/ lgbti-handlingsplan.pdf (May 12, 2020).

Schaumann, Lone. 2018. 'Præst Vover Shitstorm: Det Står i Biologibogen På Side Ét, at vi Er Skabt Som Mand Og Kvinde.' JydskeVestKysten. https://jv.dk/artikel/præst-vover-shitstorm-det-står-i-biologibogen-på-side-et-at-vi-er-skabt-som-mand-og-kvinde-2018-9-15(6) (April 7, 2020).

Schotten, C. Heike. 2016. 'Homonationalism: From Critique to Diagnosis, or We Are All Homonational Now.' International Feminist Journal of Politics 18(3): 351-370. DOI: https://doi.org/10.1080/14616742.2015.1103061

Slootmaeckers, Koen. 2019. 'Constructing European Union Identity through LGBT Equality Promotion: Crises and Shifting Othering Processes in the European Union Enlargement.' Political Studies Review 18(3): 346-361. DOI: https://doi.org/10.1177/1478929919 877624

Sørensen, Søren Skovgaard. 2018. 'Ny Kønsopfattelse Vil Splitte Danmark.' Luthersk Mission. http://dlm.dk/blog/ny-koensopfattelse-vil-splitte-danmark (September 14, 2019). 
How to cite this article: Hansen, Malte Breiding. 2021. "Between Two IIIs: Homonationalism, Gender Ideology and the Case of Denmark." Redescriptions: Political Thought, Conceptual History and Feminist Theory 24(1): 60-75. DOl: https://doi.org/10.33134/rds.339

Submitted: 05 October 2020 Accepted: 29 April $2021 \quad$ Published: 22 July 2021

Copyright: (c) 2021 The Author(s). This is an open-access article distributed under the terms of the Creative Commons Attribution 4.0 International License (CC-BY 4.0), which permits unrestricted use, distribution, and reproduction in any medium, provided the original author and source are credited. See http://creativecommons.org/licenses/by/4.0/.

Redescriptions: Political Thought, Conceptual History and

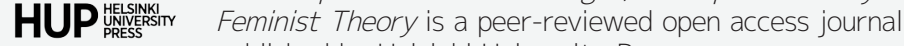
published by Helsinki University Press.
OPEN ACCESS $\precsim$ 